\title{
MOPO'ALATI TRADITION IN THE COASTAL MUSLIM COMMUNITY AT MOLOTABU BEACH BONE BOLANGO DISTRICT
}

\author{
Rahmawati, Kasim Yahiji, Muh Rusli \\ IAIN Sultan Amai Gorontalo \\ Jalan Sultan Amay, Gorontalo, Gorontalo, Indonesia \\ E-mail: rahmatjatjo@iaingorontalo.ac.id
}

\begin{abstract}
This paper elaborates on the reality of the Mopo'alati tradition in Gorontalo. It expresses respect, hopes to the sacred, and supernatural. This tradition is celebrated once a year in the month of Muharram by Muslim communities on the coast of Molotabu as an expression of gratitude and prayer of salvation in facing a hard life and challenging sea. The study used a qualitative descriptive method through ethnographic design in order to understand deeply the philosophy of the tradition and its correlation with world life. Mopo'alati tradition is urgent to be studied in order to identify the inconsistency values deviates from Islam and encouraged the ritual ceremony to Islamic nuance. The finding illustrates that Gorontalo society is very fanatical about Islam, thus all mental-spiritual activities, social activities, and traditions must be based on the philosophy of "Adati hulo huloa to Syara'ah, Syara'ah hula hula'a to Qur'ani'.It means the custom bases on religious values and the religious values base on Alquran. This philosophy contains the very deep meaning of tauhid (God values). On another side, Gorontalo society defenced the ancestor's tradition even though it deviated from Islamic values. Nowadays, Mopo'alati tradition is packaged in a ritual format by giving a more objective moral light. The ceremony was started by doing two rakaat of unobligation pray, reciting al-Waqi'ah verse, al-Rahman verse, and Yasin verse, reciting zikir, and closed by reciting doa selamat. Mopo'alati ceremony was closed by giving food, cakes, and money which collected in a ceremony to poor people around the village.
\end{abstract}

Keywords:

Tradition; Mopo'alati; Gorontalo.

\begin{abstract}
Abstrak
Artikel ini menjelaskan tentang realitas tradisi Mopo'alati di Gorontalo. Tradisi ini menunjukkan penghormatan, pengharapan kepada Yang Maha Suci dan supernatural. Tradisi ini dilaksanakan sekali dalam setahun pada bulan muharam oleh masyarakat muslim di pantai Molotabu sebagai tanda syukur dan doa persembahan dalam menghadapi hidup yang sulit dan mengarungi lautan. Penelitian ini menggunakan metode kualitatif deskriptif dengan desain etnografi untuk memahami secara mendalam nilai filosofi dari tradisi ini dan hubungannya degnan kehidupan. Tradisi Mopo'alati penting untuk dikaji untuk mengidentifikasi nilai-nilai yang tidak bernuansa Islam menjadi lebih Islami. Penelitian ini menunjukkan bahwa masyarakat Gorontalo adalah masyarakat yang sangat fanatik terhadap Islam. Oleh sebab itu, segala aktivitas mereka baik itu mental spiritual, sosial dan tradisi harus berdasarkan filosofi "adati hulo hula'a ke syara'ah,syara'ah hula hula'a ke Al-Qur'an" artinya bahwa adat harus didasarkan pada nilai-nilai agama, dan nilai-nilai agama harus didasarkan pada Al-Qur'an. Filosofi ini menunjukkan makna terdalam dari Tauhid. Di sisi lain, masyarakat Gorontalo sangat memegang kuat tradisi leluhur walau pada beberapa hal bertentangan dengan ajaran Islam. Sekarang ini, tradisi Mopo'alati dikemas dengan fomat ritual yg lebih mengutamakan aspek moral. Upacara dimulai dengan shalat sunnah dua rakaat, membaca surat Al-Waqiah, Al-Rahman, Yasin, zikir dan diakhiri dengan membaca doa selamat. Setelah itu, acara ditutup dengan memberikan makanan, kue dan uang yang sudah dikumpulkan dalam upacara kepada orang-orang miskin yang ada di desa tersebut.
\end{abstract}

Keywords:

Tradisi; Mopo'alati; Gorontalo.

DOI: $10.15575 /$ jw.v4i1.4080

Received:January 17, 2019; Accepted: March 20, 2019; Published: June 29, 2019 


\section{A. INTRODUCTION}

Principally, the culture of a nation is a plural reality, thus the picture of a nation's plurality is almost certain. Every nation in the world has a culture, but the shapes and patterns are different. On the other hand, religion as a result of the design of the accumulation of concepts, views, interpretations, and human ideas (Pattern of Behavior) through its holy text guidelines (Pattern For Behavior) is always in that plural cultural cycle, realize or not, religion as a value system in another side, has invited itself to always be in dialectic situation with the dynamic cultural cycle (cognitive system). As the value system, religion absolutely in a certain time experienced acculturation and collaboration process, even the syncretism of cultural plurality as the result of human action, or cultural plurality still exists on the human cognitive aspect and human attitude and behavior. In the study of Religion Anthropology, the relation between Islam as a religion with the study of local culture is very clear. ${ }^{1}$ The study of religion experiences development in various approaches, such as the social perspective through anthropology study. Universally, religion can be defined as a set of rules and regulation which regulates the relationship between human and their God, between human and human, and between human and their environment.

Based on the concept, there are two categories of religious reflection for humans. First; religion is sourcing from God's revelation and it is reflected based on God's revelation, in this context, religion becomes normative-dogmatic phenomena. Second; religion is reflected based on human and cultural regulation, in this context, religion becomes historical phenomena. The two categories of religion reflection, indicate the

${ }^{1}$ Clifford Geetz, Agama Jawa, Abangan Santri Dan Priyayi Dalam Kehidupan Jawa, trans. Aswab Mahasin and Bur Rasuanto (Jakarta: Pustaka Jaya, 1983), 89. See also Roibin, Relasi Antar Agama Dan Budaya Masyarakat Kontemporer (Malang: UIN Malang Press, 2009), 5. strong interconnected and interrelation and give nuance and perspective to each other.

Ali Sodikin in his article Antropologi alQur'an; Model Dialektika Wahyu dan Budaya explains the appearance of socio religion institutions in local tradition is resourcing from the culture in pre-Islam symbolically, but the content included Islam law substantially. ${ }^{2}$

Gorontalo is a province in Indonesia which very firmly adhering to the tradition handed down from the ancestor. The cultural values in Gorontalo are based on their philosophy terms "Adati hulo huloa to Syara'ah, Syara'ah hula hula'a to Qur'ani" (the custom bases on religious values and the religious values base on Alquran.) These values are reflected in all of the social activities, local customs, and local wisdom of Gorontalo society. The cultural values have not appeared automatically, but they had had a long history transformation from the King Sultan Amai era to the King Eyato era. In the era of King Eyato, the cultural values were perfected. ${ }^{3}$

King Matolodulakiki who lived in XIV centuries adopted Islam as the official religion of the kingdom and characterized it with the principle custom based on Islam, and Islam based on Alquran. ${ }^{4}$ The principle has appeared in the whole of traditional ceremonies, such as Mopoloati, Dikili, weddings, etc. Most of the ceremonies were done in the mosque. ${ }^{5}$

This research analysis used religion concept as the cultural system which regulates the relationship between human and God, human and human, and humans and their environment in religion institution forms. Zamakhsyari Dhofier and Abd.Rahman Wahid

${ }^{2}$ Ali Sodikin, Antropologi Al-Qur'an: Model Dialektika Wahyu Dan Budaya (Yogyakarta: Ar- Ruzz Media, 2008), 210.

${ }^{3}$ Hasanuddin and Basri Amin, Gorontalo Dalam Dinamika Sejarah Masa Kolonial (Yogyakarta: Ombak, 2012), 67.

${ }^{4}$ S.R. Nur, Islam Dan Etos Kerja Masyarakat Gorontalo (Jakarta: Yayasan Festival Istiqlal, 1996), 69.

${ }^{5}$ Medi Botutihe and Farhah Daulima, Tata Upaca Adat Gorontalo (Gorontalo: Pemerintah Daerah Gorontalo, 2003), 32. 
stated that religion is free of values. However, it contains moral values should be attached by the followers. Therefore, religious teaching becomes one element that forms the cultural values system. ${ }^{6}$ This perspective also argued by Durkheim who defined religion as a belief system which trusted and implemented in religious actions by a group or a community in interpreting and giving response on what they feel and trust is sacred. ${ }^{7}$ More explicitly, Geertz defined religion as a cultural system. ${ }^{8}$

H. A. Gibb agreed with Geertz's definition, he said that: Islam indeed much more than a system of theology, it is a complete civilization. ${ }^{9}$ Civilization certainly is established from the smaller element, namely tradition, and culture. When the culture has been crystallized in human life, then civilization is coming out.

The relevant research which focused on myth and the confirmation toward local wisdom value on religious value had been done by Arifuddin Ismail "Fisherman Religion, The contrast of Islam and Local Culture" (2015) and Kamaruddin Mustamin (2015) 'Maccera' Tappareng dalam Attoriolong Masyarakat Bugis Sengkang (myth analytic)." 10

Tradition ceremonial is an expression to introduce Islam rules which reflects a human connection with their spiritual life. It also integrates the plurality of human and becomes an instrument to secure a negative effect. Turner explained two aspects which motivates human to do tradition ceremonial, first, when human life comes to the transition cycle,

\footnotetext{
${ }^{6}$ Zamakhsyari and Abd. Rahman Wahid, "Penafsiran Kembali Ajaran Agama, Dua Kasus Dari Jombang," Prisma, No 3 (Jakarta, LP3ES, 1987), 27.

${ }^{7}$ Bryan S. Turner, Religion and Sosial (London: SAGE Publication, 1991), 27.

${ }^{8}$ Clifford Geertz, "Religion as Cultural System" in Antropological Approaches to the Study of Religion (London: SAGE Publication, 1996), 35-50.

${ }^{9}$ H.A.R. Gibb, Pemikiran Modern Dalam Islam (Jakarta: Rajawali Press, 2013), 67.

${ }^{10}$ Kamaruddin Amin, "Maccera' Tappareng Dalam Attoriolong Masyarakat Bugis Sengkang (Kajian Mistisisme)" (Dissertation of UIN Alauddin Makassar, 2015).
}

second when human life activities were disturbed (they make an agreement with an evil spirit, to be secure in their life). ${ }^{11}$

Tradition ceremonial is adopted as the media to increase the fisherman braveness to sail on the sea. They feel conform, enjoy and brave to sail, even though the wave is high and the weather is cloudy. Indeed, the fisherman has done this tradition ceremonial to maintain their psychological in doing their activities on the sea. Turner found the fact when he has done his research on the Ndembu community in Zambia, South Africa. Fisherman ritual activities, on the one hand, are expressions of inferiority in the presence of sea power and on the other hand, are a form of unification between humans and nature. Thus, this ritual activity becomes part of the value system of religiosity that affects the lives of the fishermen, namely the awareness of the forces behind the real nature. ${ }^{12}$

Some relevant researches have been done, namely; Ani Suryanti in her research "Upacara Adat Sedekah Laut di Pantai Cilacap" stated that sea alms custom is a tradition that is held by the fishing community of Cilacap once a year on every Suro month (Javanese calendar system) on Tuesday or Friday. This traditional ceremony contains religious as an expression of gratitude for the catches of fishermen's fish and prayers for the salvation and abundance of fish catches in the following year. ${ }^{13}$ The same research has been done by Khusnul Khotimah with the title, "Tradisi Sedekah Luat di pantai Teluk Penyu", Cilacap, stated that the character of the plurality of fishing community in South Cilacap cannot be released from the original character of Javanese who still believes to myth. Myth dominated the character and the life pattern of the fishing community.

${ }^{11}$ Y. Wartaya Winangun, Masyarakat Bebas Struktur: Liminalitas Dan Komunitas (Yogyakarta: Kanisius, 2014), 22-25.

${ }^{12}$ Daniel L. Pals, Seven Theories of Religion (Yogyakarta: Qalam, 2015), 55-60.

${ }^{13}$ Ani Suryanti, "Upacara Adat Sedekah Laut Di Pantai Cilacap," Jurnal Kajian Kebudayaan 3, no. 2 (2017): 1-8. 
However, they believe that the spirit of Kanjeng Ratu Kidul will disturb their life activity if they do not make a ritual ceremony. The other research done by Triyanto, Sumarwati, Kundharu Saddhono with the title Offering Ceremony "Sedekah Laut" in Central Java, the setting was in Cilacap. The research showed that:

The traditional marine alms ceremony on the south coast of Cilacap Regency is a tradition or custom held by the Cilacap fishing community once a year, namely every month of Suro (Javanese calendar) which coincides with Tuesday Kliwon or Friday Kliwon. This traditional ceremony contains religious meaning that is as a manifestation of gratitude for the fishermen's catch and the request for doa selamat and the abundance of fish catches the following year. This traditional ceremony also contains cultural, social and economic meanings. ${ }^{14}$ Sigit Wahyudi is also done research about the tradition of the fishing community in Pekalongan with the title, "Sedekah Laut" Tradition for The Fisherman Community in Pekalongan, Central Java. The result showed that the Sedekah Laut ritual symbolically contains lots of values that can be used by society especially the fishermen as a way of life. This tradition, as a part of cultural elements, is preserved well since the society support this event. Sometimes, Sedekah Laut ritual or Nyadran will differ in the meanings and the functions between societies in the coastal areas especially in the North Coast of Java Island and people in the interior of Java Island. ${ }^{15}$

Muhammad Bisrul Alfin, with the title Perubahan Tradisi Larung Sesaji di Kel. Karangsari Tuban Tahun 2008-2014,

\footnotetext{
${ }^{14}$ Triyanto, Sumarwati, and Kundharu Saddhono, "Offering Ceremony Sedekah Laut in Central Java," in 3rd International Conference of Arts Language And Culture, 2018, 108.

${ }^{15}$ Sarjana Sigit Wahyudi, "Sedekah Laut Tradition for in The Fhisherman Community in Pekalongan, Central Java," Journal of Coastal Development 14, no. 3 (2011): 262-70.
}

explained that the tradition of sea alms has been changed the function since 2008 . Formerly, it became a tradition, but it changed to be entertainment, economic, education, and the tool to prevent local culture as the local identity. ${ }^{16}$

Thiyas Tono Taufiq with the title Kearifan Lingkungan Berbasis Agama Komunitas Nelayan di Pesisir Banyutowo Dukuhseti Pati found that environmental wisdom in the fishing communities and coastal communities of Banyutowo is formed by the presence of social solidarity, sea alms rituals, and other local traditions. The traditions are believed to be local traditions that cannot be eliminated. They interpreted the tradition as the tool to find safety and to keep environmental balance. Moreover, the tradition contains some values, such as religious, social community, economic, and education. ${ }^{17}$

The research was done by Idrus Ruslan, Religiositas Masyarakat Pesisir; Studi atas Tradisi "Sedekah Laut" Masyarakat Kel. Kangkung Kec. Bumi Waras Kota Bandar Lampungfound that all the ritual ceremonies, such as sea alms become tools for selftransformation from the physic dimension to the sacred dimension. The transformation needs a complex process because it related to the psychological factor of their religious spirit. One of an example of transformation from physic dimension to sacred dimension, namely the offerings of buffalo head which is physically appeared- becomes sacred because it believes sacred and contains supernatural power, then the character is changed from the concrete to abstract, from visible to sacred. The various expression on sea alms also experienced the transformation from a sacred dimension to the physic dimension. It appears

\footnotetext{
${ }^{16}$ Muhammad Bisrul Alfin and Septina Alrianingrum, "Perubahan Tradisi Larung Sesaji Di Kel. Karangsari Tuban Tahun 2008-2014," Jurnal Avatara, E-Journal Pendidikan Sejarah 3, no. 3 (2015): 409-21.

${ }^{17}$ Thiyas Tono Taufiq, "Kearifan Lingkungan Berbasis Agama Komunitas Nelayan Di Pesisir Banyutowo Dukuhseti Pati," Jurnal Sosiologi Agama 11, no. 2 (2017): 259-80.
} 
on the modification of sea alms which originally became a sacred ritual and nowadays becomes a tourism object. Therefore, the sea alms have been modified from a sacred dimension to the physic dimension. $^{18}$

Sri Widati, Tradisi sedekah laut di desa Wonokerto Kabupaten Pekalongan - Kajian Perubahan Bentuk dan Fungsi, the research found that the elements of sea alms changed based on some aspects, namely time and place of celebration, the offerings, and other supported elements. The functions changed from ritual to entertainment, communication, culture preservation, education, and economic. The transformation form and function of sea alms educated the community about the sublime value of nation, spiritual value, work ethic, culture, and environmental preservation. The form and the function transformation of sea alms were influenced by the social culture community transformation which included the development of a knowledge system, economic system, and technology system. ${ }^{19}$

The previous researches above showed that the existence of sea alms, indeed, becomes the facility to pray for safety, entertainment, economy, education, local identity, etc. the process was also various, from the very simple ceremony to the very complex ceremony, however it should be done by the fishing community. Referring to those researches, the author of this research focused on "the process of Mopo'alati celebration in Moslem society at Molotabu coastal in Bone Bolango Regency". The research is ethnography which enables the researcher to find the native perspective about their life with any

${ }^{18}$ Idrus Ruslan, "Religiositas Masyarakat Pesisir; Studi Atas Tradisi Sedekah Laut Masyarakat Kel. Kangkung Kec. Bumi Waras Kota Bandar Lampung," Al-Adyan: Jurnal Lintas Agama 9, no. 2 (2014): 86-87.

${ }^{19}$ Sri Widati, "Tradisi Sedekah Laut Di Desa Wonokerto Kabupaten Pekalongan - Kajian Perubahan Bentuk Dan Fungsi," Jurnal Penelitian Pendidikan 1, no. 2 (2011): 142-48. modification. ${ }^{20}$ The research also used a case study to focus on one case intensively and in more detail. ${ }^{21}$ The case is the acculturation between Islamic law and Mopo'alatitradition. The data were collected through passive participant observation, unstructured interviews, and documentation. The sampling was purposive by choosing the key informants.

\section{B. RESULT AND DISCUSSION \\ 1. Religion and Culture Acculturation}

Religion and culture are two important elements in the community that influence each other. When Islamic teaching comes into a community, there is a conflict between them. However, Islamic teaching was coming to the Arabic community when they have a strong belief about their tradition. Therefore, Rasulullah saw. is the prophet of Islam who taught that religion should always consider the cultural factors of Arabic society at the time. Indeed, a part of al-Qur'an verses conveyed because of the cultural acculturation process. ${ }^{22}$

Religion and culture have an ambivalent correlation. Religion (Islam) and culture have their own indecency, but both are in the same ambivalent region. However, the ambivalence has not banned the manifestation of religion into cultural form. ${ }^{23}$

Considering the acculturation between Islam and local culture, Nurcholish Madjid argued that Islam and culture are two aspects that can be distinguished but they cannot be separated. Religion is absolute; it is constant even though the time and place are changed.

\footnotetext{
${ }^{20}$ A. Stuan Schlegel, Methodologi Research (Banda Aceh: Pusat Latihan Penelitian Ilmu-Ilmu Sosial Universitas Syi'ah Kula, 2014), 45.

${ }^{21}$ Lexy J. Moleng, Metodologi Penelitian Kualitatif, Edisi Revisi (Bandung: Remaja Rosda Karya, 2015), 80 .

${ }^{22}$ For example the verse about drunk and usuryconveyed step by step to make adaptation with Arabic society condition at the time. seeLuthfi AlSyaukani, Pengaruh Kristen Orientalis Terhadap Islam Liberal (Jakarta: Gema Insani Press, 2010).

${ }^{23}$ Abdurrahman Wahid, Pergulatan Negara, Agama Dan Kebudayaan (Depok: Desantara, 2001), 117.
} 
Moreover, culture is changed in accordance with the change of time and place, even though it is based on religious teaching. The existence of culture can be changed from time to time, from one place to another place. Many local cultures were lost because of the development of the era. Indeed, most of the culture based on religion, but it is never happened religion based on culture. Religion is primary and culture is secondary. Culture can change the expression of religious life because it is a sub-coordinate of religion. ${ }^{24}$

Clifford Geertz is a famous anthropologist who defined religion as: "symbol system is driving human strong everlasting spirit and motivation. Religion creates general conceptions about existence and covers the conceptions in such a way in factual condition, thus the condition and the motivation will appear very realistic". ${ }^{25}$

Two definitions indicated that religion has an important role in determining the life condition in such a way, thus it can stimulate an accurate character, either on material or spiritual and in turn, the characters will support each other. ${ }^{26}$ Meanwhile, the definition generally describes that in a religion or in reflecting a religion, there is an area that relates to the description of God. The characteristic is abstract, sacred, and absolute, and there is an area that relates to the reflection of religion and culture. The characteristic is concrete and relative.

The description of religious reflection has been explained in the previous paragraph that happened in some ethics. Clifford Geertz in his book "The Religion of Java" gave a clear description of the reality in Javanese society which reflected their religion (Islam) not only

\footnotetext{
${ }^{24}$ Norcholis Madjid, Islam Dan Kebusaayaan Indonesia: Dulu Kini, Dan Esok (Jakarta: Yayasan Festival Istiqlal, 1993), 172.

${ }^{25}$ Clifford Geertzz, The Interpretation of Culture, Trans by F. Budihardiman with the Title " Kebudayaan Dan Agama" (Yogyakarta: Kanisius, 2013), 5.

${ }^{26}$ Roger M. Kesing, The Cultural Antropologi, A Contemporary Persepective translated by R.G Soekojo with the Title "Antropologi Budaya" Suatu Perspektif Kontemporer"'(Jakarta: Erlangga, 2012), 94.
}

based on Islamic teaching but also based on cultural perspective and local wisdom. Geertz made the description after doing research for 6 years in Mojokerto, East Java in 1950. The book was translated with the title "Abangan, Santri, dan Priyayi dalam Masyarakat Jawa".

In another spectrum, the connection of new culture with other cultures indicates conflict among them. For instance, the conflict was ever happened in Minangkabau ethnic, ${ }^{27}$ and also in India America ethic. ${ }^{28}$ However, in Bugisnese society, there is harmony connection among the society, they have an institution called "pangadereng" which has been existed in society in accordance with Islamic teaching. ${ }^{29}$

Basically, culture is a description of social life, behavior, and values. From this perspective, religion, on one side is giving contribution towardthe existing cultural values, thusreligion can be accommodated with the cultural values. On the other side, religion has absolute truth, thus it cannot accommodate the cultural values. Religion should become the source of value for the development of the cultural values themselves. The reversal connection happens in this case. ${ }^{30}$

Herskovits argued that culture is a system can be adapted from one generation to the next generation. Moreover, Andreas Eppink stated that culture contains the whole meaning of value, norm, knowledge, and all of the social religious structure, etc. Edward B. Tylor argued that culture is a complex element, which included knowledge, belief, norms, art,

\footnotetext{
${ }^{27}$ Za'im Rais, The Minangkabau Traditionalists' Response to The Modernits Movement, (Montreal, MeGeel University, 2014), 131.

${ }^{28}$ Sheetal R. Shah, The Impact for Scond Generation Asin Indian Amercanas (Carbondalle.: Southerm Illinois Inuversity, 2016), 139.

${ }^{29}$ Muhamamd Yusuf, "Relevansi Pemikiran Ulam Bugis Dan Nilai Budaya Bugis (Kajian Tentang "iddah Dalam Tafsir Berbahasa Bugis Karya MUI Sulsel)," Analisis Jurnal Studi Keislaman 13, no. 1 (2013): 6768, https://doi.org/10.24042/ajsk.v13i1.642.

${ }^{30}$ Adeng Mukhtar Gazali, Antropologi Agama (Bandung: Alfabeta, 2011), 30.
} 
law, tradition, and other competencies owned by an individual as a member of society.

The correlation between culture and religion, in this context, religion is considered as real social fact, and values rules in doing social and cultural activities. Islam and other religions often were integrated with culture. Religion is not only approached through its teaching or its institution but also it is approached through another social system. Talcott Parsons stated that "religion is a commitment toward attitude, religion is not only belief, but it is attitude and character" as a social reality, it is concrete and manifested in society.

The perfection of the philosophy values is reflected in religion, custom values, and social community universally. They give important contributions and place in forming social institution which more formal and well organized. In mental-spiritual life, they are the distinguisher and the characteristic of the society.

\section{The Harmony between Tradition System and Islam Law in Performing Mopo'alati Tradition in Gorontalo}

\section{a. The Perspective of Gorontalo Moslem Community}

Raja Amai was obligated to teach Islam and adopted Islam as the legal religion of the kingdom. Therefore, the tradition and the custom should be reformed in accordance with Islamic teaching. The reformation was done by accommodating local traditions and customs. Thus the Gorontalo philosophy is known as "Syaraa topa-topango adati" means "religion is based on culture". At the time, Islam has been authority religion (the society should believe Islam as their religion because of the King's authority). At the time, tradition and custom of the ancestor dominated all aspects of Gorontalo society's life. ${ }^{31}$

\footnotetext{
${ }^{31}$ Tradition is Islamizationand Islam is integrated in tradition and in King Eyato era, become tradition in Islamizationbut still preserve the pioneer of religion leader and tradition leader as formal leader. Islamic teaching and tradition are balance in harmony
}

Therefore, the first thing is the implementation of tauhid (aqidah). Historically, in the era of King Matolodula Kiki (1550-1585 M.), religion and tradition have the same portion, both support and no domination each other, thus the philosophy was perfected into "Adati hula-hulaa to syaraa, syaraa hula-hulaa to Kiatabullah" means "tradition based on religion, religion (Islam) based on Alquran" All of the religious activities, social norms, and tradition ceremony universally should be based on this philosophy. This philosophy becomes the reflection and the characteristic of Gorontalo society.

King Eyato also governed the kingdom based on philosophy. Values system is reflected as sacred symbols based on Islamic teaching. Therefore, an ethic that becomes existence and social rules are influenced, driven, and modified by some of the values system based on Islamic rules. For instance, baitul Maal and Badan Waqafwere established by King Eyato which implemented Islam economic principle (zakat). At the time the social community activities drive through Islamic features. In reality, religion equipped with social cohesion and supplied ideology for social development. Islam legitimating is reflected in social regulation and the power of Islam legitimating lies on the balance of politics and religion. King Eyato said that the government role is moqo yiyo to Eeya wolo Nabi mursalah loqo wali $u$ sagala (the representation ofGodand Prophet Muhammad Saw) (God is the creator of human and all creature in-universe).

In many social institutions, harmony between religion and culture appears very clear, such as celebrating a birthday, wedding ceremony, and funeral ceremony. They still implement the tradition in accordance with the ancestor's tradition, but Islamic values cover the tradition. The principle can be seen from the King statement "Adati Madilidilato Bolomopoaito" (tradition is being and it is just implemented).

According to Polontalo, there are two systems of value that are maintained by the Gorontalo people, namely, First, the value 
system that comes from Islamic Sharia (sourced from the Qur'an and al-hadith). This value is very absolute and is seen as a highquality value. Second, the value system that comes from customs, this customary value system is accumulated from the deep thinking of royal officials and carried out from generation to generation. One of the goals of this customary value system is to make relations between the community and other communities live in harmony. ${ }^{32}$

Once integrated between religious values and customary values in the living order of the Gorontalo people, then: 1) Islamic colored symbols 2) the use of the verses of the Qur'an and the hadith of the Prophet. as the basis for the implementation of tradition 3) the implementation of custom must be confirmed by traditional leaders and religious leaders 4) the mosque is the first choice in implementing tradition.

There are two values system developed in Gorontalo society namely: first, religious value, the rules of the value base on Islamic rules which have high quality. The rules are included in al-Qur'an and hadith, which instructed to obey rukun Islam, rukun Iman, and rukun ihsan. Someone who obey and do all the God (Allah SWT) instruction and escape all His prohibition, thus Allah SWT guarantees him/her to be happy in world life and in eternal life. Second, tradition value, this value is focused more on the philosophy of ancestors and the kings about rules and regulations to behave in the community, in order to create harmony in society.

This is the religious description of Gorontalo society in all aspects of their activities covered by religious values and tradition values. It is indicated that society focus to preserve the philosophy "adat bersendi syara' and "syara' bersendi kitabullah".

\footnotetext{
${ }^{32}$ Polontalo, Paper on Seminar Nasional BPKI-KTI (Gorontalo, 2003), 6-12.
}

\section{b. Acculturation System of Tradition and Religion (Islamic Teaching) in Mopo'alati Ceremonyin Muslim Community at Molotabu Coastal in Bone Bolango Regency}

Gorontalo society who dwelt at the coastal beach and work as a fisherman, Mopo 'alati tradition becomes the part of their life. The tradition contains religious value as the part is separated from spiritual life which influences significantly social life and economic welfare, especially to the fishing community.

Related to the ceremony, the fishing community has their own perspective and special rules. The ceremony related to their activities in the sea which hard and challenged. Fishermen usually face the big wave and the bad weather in the sea. The sea condition is difficult to be predicted and put them in an uncertain condition. The unstable weather becomes threaten and dangerous for them. In the worst condition, they should battle their life. The condition claims them to find something which believed safety to keep their life and increase their prosperity. Therefore, they believe the supernatural power which is implemented through tradition ceremony.

The meaning of tradition contains an understanding of the relationship between the past and the present. It shows something inherited from one generation to the next, and the form of its implementation still exists today. Thus, it can be understood that tradition is something inherited or transmitted from time to time. The implementation of a traditional event is in the context of remembering, respecting, grateful, adoring, and asking for salvation to the Lord. ${ }^{33}$

In the human life cycle, from birth, adolescence, marriage, and death have a series of rituals and ceremonies throughout the stages of growth, in cultural terms, this is very important because the implementation of

\footnotetext{
${ }^{33}$ Rostiyati dkk Ani, Fungsi Upacara Tradisional, Bagi Masyarakat Pendukungnya Masa Kini (Yokyakarta: Departemen Pendidikan dan Kebudayaan, 2016), 1.
} 
culture is a prayer that is offered so that their lives are more prosperous, happy, cheap food, and safety from various disasters.

The most important thing in the process of implementing a tradition is that it must follow the mechanism outlined by the traditional stakeholders. Apart from that, there are also various symbols, offerings that have philosophical meanings and are considered very principle. All of these are rules that have been formally formalized and are believed to be true so that they become social controls and behavioral guidelines for the supporting community.

Related to the tradition of Mopo'alati, which is celebrated every year, it is believed to be able to provide blessings and prosperity for the fishing community of the coast of Molotabu. The performing of this tradition was followed by government figures, religious leaders, traditional leaders and local communities in arousing full of spiritual meaning enhanced by various customary instruments and cultural objects.

The word Mopo'alati consists of two words namely "mopoa" which means to feed (offerings) and the word "lati" means devil. So the word Mopo'alati in Gorontalo language means "to feed the devil (ruler of the sea)". Coastal communities believe that there are "rulers of the sea" who have the power to give good and evil in the sea. ${ }^{34}$

The Mopo'alati tradition is considered to be a very important tradition. The fishing community made offerings as well as requested permission from the sea authorities because the sea rulers had the power to provide many fish catches, safety from waves, winds, tsunami waves and etc. In the context of performing the Mopo'alati tradition or praying for reinforcements in Muslim communities on the coast of Molotabu, things related to cultural objects that have philosophical meanings are prepared. This is important because these objects

\footnotetext{
${ }^{34} \mathrm{Abd}$ Wahab Lathif( the secretary of Molotabu village), interview by Rusli, Molotabu Village, on April 23, 2019.
}

complement the implementation of the event, namely:

A set of food and traditional cakes, namely:

a) Hulante consisting of a set of ingredients on the tray, consisting of 3 liters of white rice, 3 liters of brown rice, 3 liters of yellow rice, above which are 7 nutmegs, 7 cloves, 7 eggs, 7 limes, 7 currency IDR 1,000 . Previously the currency consisted of ringgit or rupiah.

b) A set of incense burning material on the tray, consisting of one pulutube (fire coals), 1 basin of totabu (incense), a glass of closed drinking water, and kobokan (handwashing).

c) A set of rubbing stone tools (batu pongi'ila), namely rubbing stones to scrape turmeric, a piece mixed with a little lime, cold water, which is called "Alawahu Tilihi".

d) A set of "Tampaluda" or "Hukede" and Pomama (a place for betel and areca nut) 5) 7 toyopo pieces, a set of food, the ingredients consist of young coconut leaves containing white rice, yellow rice, brown rice, boiled eggs, one-tailed chicken (cannot be cut into pieces). Plus various kinds of traditional cakes such as wapili, kolombeng, ali wadala, tiliaya, and apangi. Completed with gapi banana, plantain, and pagata banana (lutu tahumelito or lutu lo Hulonti'o).

e) A set of food on a tray consists of a plate of bilinti or a type of fried rice mixed with chicken liver which has been cut into small pieces, a plate of whole chicken one tail and the stomach is filled with chicken eggs, two hand washings, one glass of drinking water, and two tablespoons of fruit.

f) Several kettles to be filled with clean water for prayer.

g) A white mat (amongo peya-peya or tiohu) to be occupied by religious leaders, government figures to read the Qur'an, read Barazanji, zikir, and salawat to the Prophet Muhammad, saw.

h) Pale Yilulo (tilonda'o), which is rice colored in red (symbolizing red blood / 
duhu mela on the body), yellow rice symbolizes the sum of the body in the body (yilolota), green rice symbolizes the vein / lindidu, black rice symbolizes meat/tapu and white rice symbolizes the white blood/ duhu moputio in the body

A set of clothes to say the prayer of Mopo'alati or Do'a Tolak Bala. Before the mosque is circumcised take a shower and the whole body must be hit with water. Intend to bathe circumcision to pray for refusing reinforcements. For men a set of clothes; sarong, white shirt, black skullcap, and sujadah (a special mat for praying). All the clothes to be worn are required to be given fragrant or perfumed. For women, a set of clothes; Muslim fashion white, white mukena, sujadah are required to wear fragrant or perfume. All families in the house are required to come to the mosque to pray.

The Meaning of the Instruments of Customs and Cultures in the Mopo'alati Tradition or the Prayer to Reject Bala. Hulante means offering. The contents are meaningful as

follows:

Rice 3 liters or 2 cups, as a symbol of fortune, because rice is a staple food. Nutmeg, cloves symbolize the rigidity of life, as nutmeg and cloves provide welfare because the results, also symbolize health. The egg symbolizes the origin of human events. Buluwe or Upik pinang, meaning three honors of God in the world to be achieved, namely; a) $\mathrm{Hu}^{\prime} \mathrm{u}-$ hu'umo (still wrapped in fragrant). b) malongo'olo, lebe monu (bloom is more fragrant). c) and lolante lio (already withered) remains fragrant. Kaffir lime or lemon (sophisticated lemon) symbol of the country's fragrance.Currency pieces, a symbol of tenacity in providing sufficient living necessities.A set of incense burning tools, a symbol of the journey of prayer until the presence of Allah Almighty. As a collection of fragrant incense smoke, it is expected that the prayer will be spoken, as a collection of smoke soars the presence of Allah. A series of water is to drink symbolizes peace and coolness because water is the coolness of the stomach. 9) A set of tambaluda or hukede or betel nut places, as a symbol of traditional perfection.Seven toyopo pieces that will be distributed to the rightful. The number of 7 (seven) attributes of this custom is meaning seven dignity that must be achieved by humans so that they are called perfect namely;
a) Latifah al-Qalbi
b) Latifah al-Ruh
c) Latifah al-Sirri
d) Latifah al-Akhfa
e) Latifah al-Khafy
f) Latifah Nafs al-Halikah
g) Latifah Kullu Jasad

The description above explained the things of tradition tools should be prepared in the ceremony. All the tools have their own symbols and meaning. However, the substance is to give charity and safety for the fishing community in doing their activities.

\section{c. Tradition Ceremony ofMopo'alati}

The ceremony of Mopo'alatiwas started by preparing all the traditional materials, such as food, and cake and put in front of the mosque podium. After that, the priest, government official, religious official, and community did two rekaat prayers, recited al-Fatihah verse, al-Waqi'ah, al-Rahman, and Yasin, Tahlilan, and zikir. The traditional ceremony of Mopo'alatiwas closed by giving all the food and cakes to the poor people around the village.

The fishing community who has a fishing boat, some of the food, cakes, and water were brought to the boat, and the priest recited some prayers by mentioning Prophet Nuh, Prophet Kheder, and Prophet Musa. The three of the prophets are believed by the fishing community as the power of the sea. Abd. Rahman Paside said in the interview; every fisherman who will go for sailing, must water his boat with the sacred water and recited Basmalah, after that they mentioned Prophet Nuh three times, name of Prophet Kheder three times, and name of prophet Musa three times. It is the reminder that Prophet Nuh is a prophet who made big boat when his followers experienced big flood, Prophet Kheder as the prophet of the sea, and Prophet 
Musa when he is chased by Fir'aun, he can split the sea and his followers save from Fir'aun rezim. ${ }^{35}$

In the interview with Harim Karim, it was found that the fishing community in Molotabu beach always use analogy logic in explaining the philosophy content in their activities namely;

A fishing boat has three strings in its main parts namely; life vest, main string, and ballast which symbolized as the baby in mom's womb. A life vest is the symbol of baby, main string as placental cord, and ballast is symbolized as amniotic fluid. The unity required the fishing community to maintain the boat carefully as well as to care for a baby.

Bamboo segments and buds are symbolized as foot and eyes. These parts should care fondly when these parts are broken, someone will be limping and blind, it means the production stopped.

Boat position and bamboo-segment should be symmetric because it is the symbol of mom and child relation which should be harmony, this symbol indicated the fishing production is increasing. ${ }^{36}$

The fact of research showed that the fishing community in Molotabu beach has high religious understanding but the implementation focused more on social life. Referring to the implementation of five times prayer, they almost do not do perfectly, excepted Friday prayer (because Friday is forbidden to go sailing). In doing ramadhan fasting, generally, they did perfectly only for three days, namely one day at the beginning of fasting, one day in the mid of fasting, and one day in the last of fasting. In giving zakat fitrah, they give rice, they do not want to change with money for example, because they said that money is not for eating.

\footnotetext{
${ }^{35}$ Abd.Rahman Paside (the head of Molotabu Village), interview by Rusli, Molotabu Village, on May $15,2019$.

${ }^{36}$ Harim Karim (custom leader of Molotabu beach), interview by Rusli, Molotabu Village, on April 20, 2019.
}

The results of observations and interviews of the authors with the community implementing the Mopo'alati tradition, illustrate that there are several factors that cause the emergence (trust) in the community, among others:

Inability to deal with various life challenges caused by natural turmoil of events.

The desire to live more prosperous, happy, safe so that they try to persuade the rulers of nature by offering various kinds of offerings that are usually done with a ritual ceremony. The results of the offerings are considered to be the interface with the supernatural, where humans cannot deal with them. Taming spirits that are usually destructive/hurtful. Get help from the spirits of ancestors or ancestors. ${ }^{37}$

From some of the arguments above, it can be understood that local wisdom refers to a variety of cultural assets that grow and develop in a community known, trusted, and recognized as important elements that are able to strengthen social cohesion among citizens. More than that, it is a belief system that is realized and responds to what is felt and believed to be sacred.

The relation between human life, nature, and all aspects of the environment cannot be separated from each other. Before Islam religion came into human life, society believes the supernatural power which influences human life. Harun Nasution explained that; humans feel no power, thus they put the supernatural as their power source. They think to build good relations with the power which implemented through their obligation to obey the rules and to escape the prohibition. ${ }^{38}$

D.C. Mulder was cited by Aslam Hady stated that humans think they need three things from a supernatural power, namely: 1) protection from danger and threaten 2) the necessity to accept good destiny 3) the

\footnotetext{
${ }^{37}$ Hasanuddin Ismail (The headmaster of Junior High school Molotabu), interview by Rusli, Molotabu Village, on August 14, 2019.

${ }^{38}$ Harun Nasution, Islam Ditinjau Dari Berbagai Aspeknya, fifth edition Jilid I (Jakarta: Universitas Indonesia (UI Press), 1985), 3.
} 
necessity to protect material and spiritual aspect. $^{39}$

The concept of a cultural da'wah (Islam speech) approach needs to be applied in the framework of the community understanding (rationally) that the Mopo'alati tradition with various myths, sacralization, mysticism, and meaning of the rooted symbol can be changed. Because substantially of Islam speech is actually an effort to reconstruct the notion of society that contains elements of shirk to become a Muslim society. The process of aqeedah from the traditions that are magical, animistic, dynamic, and irrational is pure aqeedah..$^{40}$

Researchers believe that in fact Islam always comes to people who are already in a variety of traditions (not cultural vacuum), so when Islam comes it does not negate and clear up existing local culture and values. Islam still accommodates and acculturates and provides more objective moral light. This principle makes Islamic religious law always harmonious with the culture that grows in the community.

Actually, when traditional values have been dominated the social life, they should be approached which a new perspective, namely "Islam collaborative". This new perspective views the reality of religious which adopts the local culture and not contradictive with Islam and even strengthens Islamic teaching through intensive transformation.

\section{The Implication of Mopo'alati Tradition Ceremony on Moslem Community at Molotabu beach in Bone Bolango Regency}

Gorontalo society had succeeded to perfect the philosophy of "Adati hula-hulaa to syaraa, syaraa hula-hulaa to Kitabullah" since governed by King Matolodula Kiki (15501585 M.). This philosophy had given a chance to develop social regulation, either in a

\footnotetext{
${ }^{39}$ Aslam Hady, Pengantar Filsafat Agama, First Edition (Jakarta: Rajawali, 1986), 49.

${ }^{40}$ M. Amin Rais, Cakrawala Islam, Antara Cita Dan Fakta (Bandung: Mizan, 1991), 26.
}

spiritual dimension or in the tradition dimension.

The implication of Mopo'alatitradition ceremony on Moslem community at Molotabu beach can be seen from the explanation as follows;

In Mopo'alatitradition, Islamic teaching is interpreting in a very concrete form, where Islam becomes the spirit from all activities to find happiness either in world life or in eternal life. The fish harvest ceremony was held on ramadhan month becomes the implementation of being thankful to Allah SWT, they believe that Allah will pour more when the human always conveys their thanks.

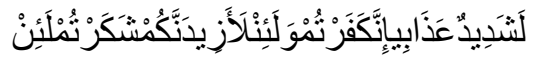

Indeed when you convey many thanks, absolutely Allah will increase His blessing to you, and when you deny His blessing, indeed the doom is very poignant.

The verses which recited by the priest in the local language indicated that the fishing community is familiar with Islamic teachings, such as reciting shalawat, al-Fatihah, Yasin, etc.as the opening of prayer. Conveying prayers reflect the harmony relation between human and nature. Forest is the place to find wood for boat making, the sea is the source of fish, they should be respected by giving alms in the ceremony.

Confirming Islamic teaching and Mopo'alatitradition which cover in symbol becomes the best way to come out of symbolic conflict, thus it can be accepted by the fishing community because they will not be lost their local identity. The habit to mention Prophet Khedher after reciting shalawat when they are in the sea to install piles, to mention Prophet Nuh when they are meshing net, indicate the close spiritual relationship between the fisherman and God (Allah SWT).

The symbolic meaning of the cultural material is directed on Islamic teaching which they believe only to Allah SWT, they install piles in odds number because Allah SWT like something is odd. 
In addition, food and cakes were prepared for Mopo'alati ceremony are the symbol of being optimistic in praying. The symbols indicate the implementation of prayer which unspelled. It is proven that the fishing community believes about Allah's power in regulating this world. They believe that how big the wave is or how dangerous the weather is, the determiner is Allah Swt, thus they must pray all the time.

The other implementation is the fishing community has an honest and fair character. They implemented the "pamali" principle where they cannot do some activities which break the rules during they are sailing. The principle is also applicable to their families. The implementation of pamali is not to take anything out of their area. The fishing community in Molotabu beach is very careful in doing their work in the sea, they perceive the charity is not only to fulfill their need but also it should give happiness in their life. It is useless to own glory prosperity by doing the cheating. This character is the implementation of Islamic values which recommend escaping the devil action. The honesty is the implementation of self-correction when going sailing, for example, it is forbidden to eat some forbidden food if it happens, the worst thing will be experienced by their selves and their families. The fishing community believes that a good generation grows from good input. The honesty becomes the character of most of the fishermen in Molotabu beach.

The next implication is a generous and helpful character implemented by the fishing community at Molotabu beach in their daily activities. Principally, they go sailing to catch some fishes for selling, but they do not forget as the social individuals they have to share their fishing with others.

\section{CONCLUSION}

The acculturation of Islamic teaching and Mopo'alatitradition were based on the philosophy of "Adat hula-hulaa to syara ', Syara' hula-hulaa to Qur'ani" (adat bersendikan syarak and syarak based on the books of Allah). From this philosophy two values systems are adopted, namely; 1). Islamic values based on the Qur'an and alhadith. 2). Customary values based on traditional formatted ancestral customs and institutions within the community.

The implementation of the Mopo'alatitradition in the $1960 \mathrm{~s}$ was still uncivilized. The pelola lo kambungu (the leaders) believe that the authority of the sea has the power to give good and / or evil to the fishing community. This is what encourages them to give offerings, read spells and offerings of dances. However, around the 1970s, Islamic propaganda increasingly developed the Muslim coastal community of Molotabu began to change its religious understanding. Thus the implementation of the Mopo'alati tradition changed to the prayer of "Reject Bala" this activity reflected Islamic nuances such as; reading the prayer, remembrance, reading the letter of Yasin, the letter Tabarakah, al-Waqi'ah, etc.

The Mopo'alaticeremony is considered urgent because of the problem of work in the hard and challenging sea. Fishermen face waves, strong winds, and erratic weather. Sea conditions are difficult to predict, making fishermen in the scope of uncertainty. Changing natural weather is a life threat. Even at the worst level, life is at stake in their profession. This condition requires the fishermen to look for a backrest that can support the smooth running of the work; therefore the fishing community has a very intimate bond with supernatural powers embodied through various rituals.

\section{BIBLOGRAPHY}

Al-Syaukani, Luthfi. Pengaruh Kristen Orientalis Terhadap Islam Liberal. Jakarta: Gema Insani Press, 2010.

Alfin, Muhammad Bisrul, and Septina Alrianingrum. "Perubahan Tradisi Larung Sesaji Di Kel. Karangsari Tuban Tahun 2008-2014." Jurnal Avatara, E-Journal Pendidikan Sejarah 3, no. 3 (2015): 40921.

Amin, Kamaruddin. 'Maccera' Tappareng Dalam Attoriolong Masyarakat Bugis 
Sengkang (Kajian Mistisisme)." UIN Alauddin Makassar, 2015.

Botutihe, Medi, and Farhah Daulima. Tata Upaca Adat Gorontalo. Gorontalo: Pemerintah Daerah Gorontalo, 2003.

Dhofier, Zamakhsyari, and Abd. Rahman Wahid. "Penafsiran Kembali Ajaran Agama, Dua Kasus Dari Jombang." Prisma, 1987.

Gazali, Adeng Mukhtar. Antropologi Agama. Bandung: Alfabeta, 2011.

Geertz, Clifford. "Religion as Cultural System," 35-50. London: SAGE Publication, 1996.

Geertzz, Clifford. Kebudayaan Dan Agama. Yogyakarta: Kanisius, 2013.

Geetz, Clifford. Agama Jawa, Abangan Santri Dan Priyayi Dalam Kehidupan Jawa. Translated by Aswab Mahasin and Bur Rasuanto. Jakarta: Pustaka Jaya, 1983.

Gibb, H.A.R. Pemikiran Modern Dalam Islam. Jakarta: Rajawali Press, 2013.

Hady, Aslam. Pengantar Filsafat Agama. Jakarta: Rajawali, 1986.

Hasanuddin, and Basri Amin. Gorontalo Dalam Dinamika Sejarah Masa Kolonial. Yogyakarta: Ombak, 2012.

Kesing, Roger M. Antropologi Budaya: Suatu Perspektif Kontemporer. Translated by R.G Soekojo. Jakarta: Erlangga, 2012.

Madjid, Norcholis. Islam Dan Kebusaayaan Indonesia: Dulu Kini, Dan Esok. Jakarta: Yayasan Festival Istiqlal, 1993.

Moleng, Lexy J. Metodologi Penelitian Kualitatif. Bandung: Remaja Rosda Karya, 2015.

Nasution, Harun. Islam Ditinjau Dari Berbagai Aspeknya. Jakarta: Universitas Indonesia (UI Press), 1985.

Nur, S.R. Islam Dan Etos Kerja Masyarakat Gorontalo. Jakarta: Yayasan Festival Istiqlal, 1996.

Pals, Daniel L. Seven Theories of Religion. Yogyakarta: Qalam, 2001.

Polontalo, Ibrahim. "Upaya-Upaya Mempertahankan Sistem Nilai Adat Bersendikan Syara', Syara' Bersendikan Kitabullah Sebagai Prinsip Adat Gorontalo.” In Dialog Budaya Balai Kajian
Dan Nilai Tradisional Manado. Gorontalo, 2003.

Rais, M. Amin. Cakrawala Islam, Antara Cita Dan Fakta. Bandung: Mizan, 1991.

Rais, Za'im. The Minangkabau Traditionalists' Response to The Modernits Movement. Montreal: McGill University, 2014.

Roibin. Relasi Antar Agama Dan Budaya Masyarakat Kontemporer. Malang: UIN Malang Press, 2009.

Rostiyati, Ani, Endah Susilantini, Sri Sumarsih, and H.J. Wibowo. Fungsi Upacara Tradisional, Bagi Masyarakat Pendukungnya Masa Kini. Yogyakarta: Departemen Pendidikan dan Kebudayaan, 2016.

Ruslan, Idrus. "Religiositas Masyarakat Pesisir; Studi Atas Tradisi Sedekah Laut Masyarakat Kel. Kangkung Kec. Bumi Waras Kota Bandar Lampung." Al-Adyan: Jurnal Lintas Agama 9, no. 2 (2014): 8687.

Schlegel, A. Stuan. Methodologi Research. Banda Aceh: Pusat Latihan Penelitian Ilmu-Ilmu Sosial Universitas Syi'ah Kula, 2014.

Shah, Sheetal R. The Impact for Scond Generation Asin Indian Amercanas. Carbondalle: Southerm Illinois Inuversity, 2016.

Sodikin, Ali. Antropologi Al-Qur'an: Model Dialektika Wahyu Dan Budaya. Yogyakarta: Ar- Ruzz Media, 2008.

Suryanti, Ani. "Upacara Adat Sedekah Laut Di Pantai Cilacap." Jurnal Kajian Kebudayaan 3, no. 2 (2017): 1-8.

Taufiq, Thiyas Tono. "Kearifan Lingkungan Berbasis Agama Komunitas Nelayan Di Pesisir Banyutowo Dukuhseti Pati." Jurnal Sosiologi Agama 11, no. 2 (2017): 259-80.

Triyanto, Sumarwati, and Kundharu Saddhono. "Offering Ceremony Sedekah Laut in Central Java." In 3rd International Conference of Arts Language And Culture, 108, 2018.

Turner, Bryan S. Religion and Sosial. London: SAGE Publication, 1991.

Wahid, Abdurrahman. Pergulatan Negara, 
Mopo'alati Tradition in The Coastal Muslim Community at Molotabu Beach Bone Bolango District

Agama Dan Kebudayaan. Depok: Berbahasa Bugis Karya MUI Sulsel)." Desantara, 2001.

Analisis Jurnal Studi Keislaman 13, no. 1

Wahyudi, Sarjana Sigit. "Sedekah Laut Tradition for in The Fhisherman Community in Pekalongan, Central Java." Journal of Coastal Development 14, no. 3 (2011): 262-70.

Widati, Sri. "Tradisi Sedekah Laut Di Desa Wonokerto Kabupaten Pekalongan - Kajian Perubahan Bentuk Dan Fungsi." Jurnal Penelitian Pendidikan 1, no. 2 (2011): 14248.

Winangun, Y. Wartaya. Masyarakat Bebas Struktur: Liminalitas Dan Komunitas. Yogyakarta: Kanisius, 2014.

Yusuf, Muhamamd. "Relevansi Pemikiran Ulam Bugis Dan Nilai Budaya Bugis (Kajian Tentang 'iddah Dalam Tafsir (2013): 67-68. https://doi.org/10.24042/ajsk.v13i1.642.

\section{INTERVIEW}

Abd Wahab Lathif (the secretary of Molotabu village), interview by Rusli. Molotabu Village. August 14, 2019.

Abd. Rahman Paside (the head of Molotabu Village), interview by Rusli. Molotabu Village. May 15, 2019.

Harim Karim (custom leader of Molotabu beach), interview by Rusli. Molotabu Village. April 20, 2019.

Hasanuddin Ismail (The headmaster of Junior High school Molotabu), interview by Rusli. Molotabu Village. August 14, 2019. 